search Center of the Russian Academy of Sciences. 129 p. 1 electron. opt. disc $12 \mathrm{~cm}$. (CD-ROM). (In Russ.).

Zubok, Ju. A. and Chuprov, V. I. (1996) Problemy vtorichnoj zanjatosti uchashhejsja molodezhi: sostojanie i perspektivy. Sociologicheskie issledovanija, no. 9, pp. 88-95. (In Russ.).

Zubok, Ju. A. and Chuprov, V. I. (2015) Molodye specialisty: podgotovka i vostrebovannost' na rynke truda. Sociologicheskie issledovanija, no. 5, pp. 114-122. (In Russ.).

Bridging the gap: New opportunities for 16-18 year olds not in education, employment or training. Report by the Social Exclusion Unit. July 1999. [online] Available at: https://dera.ioe. ac.uk//15119/ (accessed: 01.06.2021).

Standing G. (2011) The Precariat: The New Dangerous Class. London, New York : Bloomsbury Academic. 198 p.

Submission date: 01.06.2021.

Воробьева Ирина Владимировна - кандидат социологических наук, доцент кафедры теории и истории социологии Российского государственного гуманитарного университета, доцент. Адрес: 125993, Россия, г. Москва, Миусская пл., А. 6. Тел.: +7 (903) 220-79-00. Эл. адрес: vorobyova.irina@list.ru

Vorobyova Irina Vladimirovna, Candidate of Sociology, Associate Professor, Department of Theory and History of Sociology, Russian State University for the Humanities. Postal address: 6, Miusskaya Sq., Moscow, Russian Federation, 125993. Tel.: +7 (903) 220-79-00. E-mail: vorobyova.irina@list.ru

DOI: $10.17805 /$ zpu.2021.3.8

\title{
Социологическое изучение религиозности в детской и в молодежной среде в Среднем Поволжье в позднесоветский период
}

\author{
М. В. КИЛЬДЕЕВ \\ РЕСПУБЛИКАНСКИЙ ЦЕНТР МОЛОДЕЖНЫХ, ИННОВАЦИОННЫХ \\ И ПРОФИЛАКТИЧЕСКИХ ПРОГРАММ
}

Цель исследования - рассмотреть специфику социологического изучения мировоззрения детей и молодежи на материале советской социологии религии. Научная новизна заключается в том, что социологические данные использованы как источник данных о том, как в детской и молодежной среде преломлялись общественные тенденции секуляризации, идеологического диктата и воспроизводства религиозности. Наиболее заметным итогом опросов в школьных стенах является то, что они проходили с игнорированием юридических и этических норм участия несовершеннолетних в научных исследованиях. Имеющийся материал изучения молодежи позволил провести сопоставительный анализ состояния мировоззрения советской молодежи, с одной стороны, в татарской среде Горьковской области, с другой - в интернациональной среде студенчества г. Казани. Данные позволяют утверждать о значительной степени секуляризованности интернационального советского студенчества, которое в приведенном кейсе на 80\% состояло из выходцев из семей служащих и рабочих. Зафисированы также непредвиденные результаты 
социализации советской молодежи в виде широкого распространения идеологического конформизма и религиозного индифферентизма. Однако вопреки аксиомам советское общество не было однородным. В нем во все времена существовали социальные анклавы, на которые не распространялись общие социальные тенденции. Так, татарская молодежь Горьковской области находилась под сильным влиянием мусульманской религии.

Ключевые слова: советская социология религии; комсомол; пионерская организация; латентная религиозность; идеологический конформизм; религиозный индифферентизм

\section{ВВЕАЕНИЕ}

$\prod^{\mathrm{s} m}$ редлагаемая читателю работа основана на социолого-историческом исследовании, осуществленном путем поиска и изучения доступных социологических данных и архивных материалов.

Цель исследования - рассмотреть специфику социологического изучения мировоззрения советских детей и молодежи на материале советской социологии религии. Социология религии зародилась в СССР в поздний период развития страны, в 1960-х гг., когда появился ярко выраженный общественный запрос на ее услуги и условия для проведения социальных исследований. Атеизация и секуляризация являлись составной частью советского проекта модернизации. Советский атеизм, несомненно, наложил отпечаток на духовную жизнь народов современной Российской Федерации. И современная массовая религиозность (в таких ее проявлениях, как фемининность, обрядовость, приватность), и современный атеизм во многом являются продуктом той эпохи.

Объектами исследования являются социально-демографические категории советских детей и молодежи. К детям в нашем тексте относятся учащиеся школ начального и основного уровня. Молодежью именуются в соответствии с советской традицией лица в возрасте от 14 до 28 лет.

Актуальность данного исследования определяется тем, что советский опыт воспитания подрастающего поколения, особенно военно-патриотическое воспитание, в настоящее время активно эксплуатируется. Несомненно, что методы «научноатеистического воспитания» также могут быть в какой-то мере востребованы.

Эмпирическую базу исследования составили материалы социологических исследований, проведенных в Среднем Поволжье начиная с середины 1960-х гг. и заканчивая второй половиной 1980-х. Источником данных являются как социологические и научно-атеистические публикации того исторического периода, так и ранее не публиковавшиеся материалы, обнаруженные автором в архивах. Тематические обзоры исследований представлены в обзорах И. А. Галицкой (Галицкая, 1969) и И. С. Аошаковой (Аошакова, 1993). Советские исследования в этой области представляли собой преимущественно однотипные эмпирические исследования по проблемам коммунистического воспитания. Теоретически существование верующих школьников и студентов было исключено исследовательской парадигмой. Прямые цифры о количестве верующих, отличающиеся от нуля, в публикациях практически не встречаются (Иебедев, 1973: 201). Вполне возможно, что в отдельных случаях они изымались советской цензурой. Но цифры, свидетельствующие о религиозности родителей, об участии молодежи в обрядах, о положительном отношении к отдельным религиозным обрядам и к религии в целом, встречаются (Орлов, 1973). В основном влияние религии на детей и юношество рассматривалось не через религиозность, а через понятие «влияние религии». Влияние религии отличается от религиозности тем, что распространяется не только на верующих людей. В качестве 
источников религиозного воздействия рассматривались: слушание проповедей, приглашение служителей культа на семейные торжества (там же: 101).

Значительное внимание к религиозности молодежи в СССР проявляла зарубежная социология. Этот интерес впервые проявился в Гарвардском проекте, реализованном в первые годы холодной войны. Научное руководство этим проектом по изучению устройства советского общества осуществлял известный социолог А. Инкельс. Исследователями было сделано важное наблюдение об универсальном для советского общества конфликте поколений на почве разногласий между уважением к народным традициям, религиозной верой и между преданностью советской системе (Inkeles, Bauer, 1968: 216).

Сегодня, когда в России сложилась новая обществоведческая парадигма, интерес к теме диктуется необходимостью научного изучения социальных реалий советского периода. Ааже с поправкой на характер и задачи, стоявшие перед наукой в тот период, социология религии - единственный источник знаний по такой стороне религиозности, как ее преломление в отдельных социально-демографических группах населения, в том числе среди детей и молодежи. Итоги исследования могут быть актуальны при описании этапов развития социологии как научной дисциплины и для осмысления места социологической науки в современном российском обществе.

\section{АЕТСКАЯ РЕАИГИОЗНОСТЬ}

Опросы среди школьников были начаты одновременно с первыми опросами взрослого населения в 1920-х гг. Опросы и тестирования должны были иллюстрировать атеистическую, антирелигиозную результативность воспитательного процесса в советских школах. Большая советская энциклопедия сообщает: «...атеистическое воспитание школьников осуществляется как в ходе обучения основам наук, когда закладывается фундамент последовательного материалистического мировоззрения, так и в процессе внешкольной работы. В школе необходимо научно достоверно разъяснять учащимся антинаучную и реакционную сущность религии в формах, доступных детям соответствующих возрастов» (Глаголев, Евдокимов, 1970: 370).

Известный педагог и психолог П. П. Блонский, в 1929 г. изучавший состояние религиозности московских школьников, констатирует ослабление религиозности учеников школ первой ступени. С 60\% у поступивших в первый класс она падает до $25 \%$ в четвертом классе (Иевада, 1965: 217). Процесс целенаправленной трансформации сознания школьников демонстрирует и опрос учеников татаро-башкирской семилетней школы г. Свердловска, проведенный в 1927 г. Отнесли себя к верующим $39,5 \%$ учащихся, к неверующим - 23,7\%, оставшиеся $36,8 \%$ не смогли отнести себя ни к первой, ни ко второй категории (Старостин, 2009: 88).

Ученые, проводившие «Гарвардский проект», выясняли путем интервью с выходцами из СССР принципы, на которых построено советское общество. Изучив то, каким образом происходила социализация подрастающего поколения в советских семьях, они пришли к выводу, что «согласованное влияние школы, молодежных организаций и средств массовой информации подталкивало детей к тому, чтобы они стали антирелигиозными и прорежимными» (Inkeles, Bauer, 1968: 216). С родительской точки зрения, в результате сильного антирелигиозного и просоветского воздействия дети отдалялись от них. Аети в свою очередь начинали считать родителей отсталыми и невежественными (там же). 
Советскими законами обучение несовершеннолетних религии было запрещено. Тем, кто создавал препятствия на пути к приобщению детей к религиозным ценностям и системам и интенсивно обрабатывал их «атеистическим воспитанием», искоренение религии представлялось делом считаных десятилетий.

Институт научного атеизма при Академии общественных наук, начавший в 1965 г. практику социологического обследования населения страны, в качестве отдельных, отличных от всего населения объектов, рассматривал категории верующих, сельских жителей и женщин. Аети в качестве объекта обследования на тот период (в 1965-1966 гг.) не рассматривались, на то не имелось никакого юридического обоснования. Тем не менее, выполняя указание ЦК КПСС о создании системы атеистического воспитания, конкретно-социологические исследования активно проникают в школы.

Качество данных, получаемых при опросах школьников, позволяет оценить цитата одного из авторов, проводивших исследования среди школьников в Орловской области РСФСР (и чьи умозаключения не остались незамеченными для зарубежных аналитиков: Fletcher, 1976: 185): «...руководители и педагоги отдельных школ из ложно понимаемых соображений престижа пытались оказать давление на учащихся, проводя непосредственно перед анкетированием запоздалую воспитательную работу» (Алексеев, 1967: 145).

К концу 1960-х гг. исследования среди школьников, зачастую парадоксальные итоги которых требовалось объяснять и которые с трудом помещались в заранее заготовленные теоретические конструкции, становятся головной болью для партийных органов. Аиректор Института научного атеизма А. Ф. Окулов в 1969 г. высказал сомнения в их целесообразности. «Меня беспокоит вопрос об исследовании религиозности детей... У нас здесь большой ясности нет. Говорилось о религиозности детей в пятом классе. Что это за религиозность? <...> Мы залезли в школу, не знаем зачем, и как мы будем оттуда вылезать» (РГАСПИ. Ф. 606. Оп. 4. А. 93. А. 75).

Юридические и этические вопросы участия несовершеннолетних в соцопросах никак не оговаривались. Современные этические нормы участия в научных исследованиях и опытах предполагают добровольное согласие на участие в исследовании, отсутствие негативных последствий за отказ в участии и возможность выйти из исследования на любом этапе (Аетство XXI века, 2018: 433). Очевидно, что в условиях атмосферы «атеистического воспитания» изначально неанонимные опросы, проводимые в советских школах, могли бы обладать научной ценностью лишь при условии, что целенаправленное атеистическое влияние педагогов на школьников сведено к нулю. Неудивительно, что в своей массе советские дети и подростки при опросах демонстрировали конформное поведение, поскольку они, как ни одна другая категория респондентов, не были защищены от влияния организаторов обследования.

Несмотря на то что тема религиозности глубоко затрагивает личные вопросы жизни исследуемых, правовая регуляция прав детей как участников социальных исследований в СССР не осуществлялась (Русакова, 2014)1․ Вопросы этики участия детей в подобных исследованиях: добровольное и информированное участие, принцип конфиденциальности - должны соблюдаться неукоснительно.

В 1974 г. в газете республиканского обкома «Социалистик Татарстан» вышла статья под заголовком «Куда ведет успокоенность?» Поводом послужила гибель ребенка из села Киракитян Арожжановского района в результате неудачной процедуры суннат (ритуальное обрезание). Попутно выяснилось, что по плану атеис- 
тического воспитания в Марсовской средней школе этого села было проведено анкетирование в шестых классах. В анкете содержались вопросы: «Существует ли Аллах?», «Аержат ли уразу у вас в семье и у соседей?».

В классе 6 «а» треть детей, а в классе 6 «б» две трети $(68,7 \%)$ дали ответ, что «Аллах существует». Различия в ответах между классами в райкоме В $\Lambda$ КСМ объяснили тем, что в классе «б» были собраны дети из Верхнего Каракитяна, где население религиозное, а среди молодежи мало членов В $\Lambda$ КСМ, поэтому «дети могли оказаться под религиозным влиянием». Ответственность за результаты опроса, которые были доведены до областного комитета В $\Lambda$ КСМ, была возложена на руководство школы и на школьную атеистическую секцию, «которые не имели права» задавать вопросы о существовании Аллаха детям, которые «знают и про космос, и про шарообразность Земли» (Рафиков, 1974: 4). В вину атеистической секции поставили и второй вопрос, о мусульманском посте. Ураза, посчитав, что он «не имеет отношения к атеистическому воспитанию» (там же). Подобная реакция на соцопросы достаточно типична для общественной атмосферы брежневских времен. Раздражение руководства комсомола Татарии, по всей видимости, было вызвано тем, что социологический инструментарий затронул проблемную с точки зрения идеологии и поэтому запретную зону.

Опросы с участием школьников-татар выявляли примерно те же тенденции, что и опросы среди взрослых, в частности - более высокую религиозность среди татар по сравнению с соседними народами. В 1979 г. в Свердловской области отделом пропаганды и агитации обкома было проведено анкетирование в четырех сельских школах Артинского района. Были опрошены 468 школьников 3-10-х классов, в том числе 221 - русской национальности, 159 - татарской и 88 - марийской. Было выявлено, что 89,8\% школьников являются неверующими, 64,9\% - активными атеистами, 3,4\% испытывали на себе религиозное влияние в семье. Последняя категория особенно характерна для школьников-татар, среди которых о таком влиянии признались $7 \%$ (среди русских - 1,8\%, среди марийцев - 1,1\%) (Буйначев, 1982: 44 ).

О степени адаптивности и конформизма советских верующих к советскому строю говорит тот факт, что дети верующих мусульман не избегали вступления в пионерские, комсомольские организации. Эти структуры служили инструментами направления молодого поколения в необходимое власти конструктивное русло. Неучастие в них считалось признаком девиантности. Например, в весьма религиозном селе Октябрьское Пензенской области в пионерской организации состояли все дети пионерского возраста, в В $\Lambda$ КСМ состояли $90 \%$ старшеклассников. При этом, как показало исследование, в семьях у $94 \%$ опрошенных старшеклассников соблюдалась ураза, у $96 \%$ - отмечались мусульманские праздники, а у половины детей в семье было принято посещать мечеть (Орлов, 1977: 147). Что касается школьного атеистического воспитания, то очевидно, что у детей из семей верующих имелся определенный иммунитет и невосприимчивость к официальной антирелигиозной идеологии. Несомненно, что проявлялась эта невосприимчивость в том числе и при различных опросах.

\section{ИССАЕАОВАНИЯ СРЕАИ МОАОАЕЖИ}

Молодежь представляет собой потенциальную социальную силу, которая, реализуя свои способности и устремления, способна возглавить общественные преобразования. Субъектность молодежи в свободном обществе реализуется через ее самоорганизацию и через свободное участие в общественных, общественно-полити- 
ческих, национальных, конфессиональных, (суб)культурных и прочих объединениях. Советская система лишала молодежь права выбора, игнорируя ее специфические интересы, устремления и проблемы. Природная социальная активность молодежи подменялась разрешенной активностью под контролем комсомола. Аюбая неформальная активность, например на почве интереса к западной музыке (особенно к металлу и панку), к спорту (карате, восточным боевым искусствам), вызывала подозрения в идеологической нелояльности и пресекалась властями. Аналогично несанкционированная конфессиональная (а также региональная, национальная, этнокультурная) идентичность среди молодежи воспринималась с подозрением как проявление чуждых для советского общества «пережитков прошлого».

В зарождавшейся советской социологии, несмотря на большое число работ, где молодежь рассматривалась как активный субъект общественных отношений, преобладал упрощенный подход к молодежи как к лишенному субъектности объекту, подлежащему формированию со стороны государственных институтов (Горшков, Шереги, 2016: 34). В советских версиях социологии молодежи тема религиозности полностью отсутствовала. Единственный генератор социологических данных о религиозности молодежи - Институт научного атеизма и его опорные пункты, поэтому исследования в этой области отличались однообразием подходов и методик. Социологи религии проводили опросы преимущественно в стенах учебных заведений, по одноликим методикам.

Аля того чтобы правильно понять значение опросов, проводимых в учебных заведениях, необходимо иметь представление о программируемом советским образованием отношении к религии и атеизму. Научно-атеистическое воспитание, наряду с Моральным кодексом строителя коммунизма, советским патриотизмом и пролетарским интернационализмом, было составной частью советской педагогики (Ильина, 1968). Ключевая роль в формировании советской идентичности отводилась школе и безальтернативным общественным организациям - пионерии и ВАКСМ. Поэтому ответы на анкетные вопросы, касавшиеся мировоззрения личности, были не просто «искренними» или «неискренними», тривиальными или информативными, они были «верными» и «неверными». С помощью опросов фиксировалось, насколько закреплено в сознании обучаемого материалистическое и атеистическое мировоззрение.

В той мере, в которой данные социологических исследований могут быть сопоставимы, они дают нам некоторое представление о степени секуляризованности советской молодежи. И в некоторой степени позволяют выяснить, входила ли религиозная идентичность в число жизненных ценностей молодежи.

Одним из первых исследований влияния религии на молодежь в Среднем Поволжье стало изучение татарской молодежи Горьковской области РСФСР А. М. Орловым в 1971 г. Опрос охватил 355 татар, среди которых были жители шести татарских сел и горожане - рабочие промышленных предприятий и студенты вузов г. Горький. В фокусе исследования находилось отношение молодежи к мусульманской религии. На вопрос «Что дает религия людям?» дали ответ, что религия приносит вред 159 человек (44,7\%), но при этом с тем, что ислам также приносит вред, согласились всего 93 человека (26,2\%). Многие выбрали варианты ответа «вред приносят другие религии, а ислам вреда не приносит»- 34 человека $(9,6 \%)$, «ислам, как и другие религии, не приносит ни вреда, ни пользы» - 41 чел. $(11,5 \%)$ и «ислам полезен» - 13 человек $(3,7 \%)$. Воспользовались возможностью уклониться от отве- 
та, выбрав вариант «не задумывались над этим вопросом», 98 человек, или 27,5\% (Орлов, 1973: 86). Таким образом, вопреки полученному атеистическому воспитанию, молодые татары по большей части не разделяли точку зрения о «реакционной» роли ислама в современном, т. е. социалистическом, обществе. Аля сравнения приведем данные опроса молодежи в масштабах всей Горьковской области. На вопрос «Как вы относитесь к религии?» ответили, что религия приносит вред $52,9 \%$, не приносит ни вреда, ни пользы - 9,2\%; приносит пользу - 0,9\%. Уклонились от ответа, выбрав вариант «не задумывались», $35,4 \%$.

Респондентам задавался также вопрос о вере, однако А. М. Орлов в своей статье обходит стороной итоги этого вопроса. Тем не менее, исходя из того что Орлов приводит сведения о том, что неверующими себя назвали только 166 человек, или 46,7\% (там же: 87), нетрудно понять, что среди молодежи выявлен немалый процент верующих.

В опрошенной категории большая часть молодежи социализировалась в сельской местности, в условиях компактного проживания татарской национальности. У той ее части, которая усвоила антирелигиозность как часть советской идентичности, она была адресована к "религии вообще», а не к исламу. Взаимоотношения молодежи с религиозной сферой мы можем обозначить как сильное религиозное влияние. Заметное тяготение к исламу как к национальной религии отличало татарскую молодежь от секуляризованной русской молодежи.

Сходные свидетельства сильного влияния ислама на татарскую молодежь были получены в Пензенской области. Пензенский опорный пункт Института научного атеизма изучал религиозное влияние верующих родственников на учащихся старших классов татарских школ. Опросы были проведены в 1971 г. в двух районах. В школе села Средняя Елюзань были проанкетированы 77 десятиклассников. 29 опрошенных заявили о своей вере в Аллаха, 7 - о регулярном посещении мечети, 23 - не видели противоречий между наукой и религией. Многие сообщали о своем положительном отношении к религиозным праздникам, обрядам, к религиозности других людей (РГАСПИ. Ф. 606. Оп. 4. А. 144. А. 86). Результаты опроса стали, по мнению заказчиков, «результатом, с одной стороны, повышенной религиозности населения в данном селе, где действует одна из сильнейших мечетей в области, и с Аругой - результатом запущенности атеистической работы в школе» (РГАСПИ. Ф. 606. Оп. 4. А. 144. А. 87).

В 1980 г. Казанский опорный пункт Института научного атеизма провел изучение атеистической убежденности студентов. Оно охватило 1238 первокурсников шести казанских вузов, в которых было отобрано по две учебные группы с каждого из факультетов. В 1983 г. проведено повторное исследование в тех же учебных группах, но уже четвертых курсов (ЦГАИПА РТ. Ф. 15. Оп. 12. А. 250в. А. 67-84). В этот раз был охвачен 1041 студент. Таким образом, исследование стало лонгитюдным, т. е. позволяло отслеживать изменения объектов в среднесрочной перспективе. В обоих случаях использовался метод группового анкетирования. Результаты исследования актуальны и в настоящее время, поскольку дают отличное представление о социальном, этническом составе и о мировоззрении студенчества начала восьмидесятых.

Социально-демографические данные имеют особую ценность, поскольку по правилам советской цензуры столь подробные сведения не могли быть опубликованы. По состоянию на 1983 г. среди опрошенных студентов женщин было 52,6\%, мужчин $-47,4 \%$. По национальности: русских $-38,6 \%$, татар $-46,3 \%$. Считают род- 
ным русский язык $-51,4 \%$, татарский $-36,4 \%$, оба языка одновременно $-2,6 \%$. По социальному происхождению отнесли себя к служащим 45,4\%, к выходцам из рабочих семей $33 \%$ опрошенных. Происходят из семей колхозников 20,1\%. Городские школы окончили 57,8\%, сельские школы - 39,4\%.

Среди первокурсников $63 \%$ опрошенных ответили, что среди близких им людей есть верующие. Это родители - 7,1\% или родственники из старших поколений $(51,4 \%)$. Цифра верующих родителей видится нам заниженной. По всей видимости, респонденты проявили некоторую осторожность. Аалее, всего $0,7 \%$ опрошенных в 1980 г. ответили, что испытали на себе сильное религиозное влияние в семье (в 1983 г. $-2 \%$ ).

Обычная для советской социологии религии типология личности по отношению к религии относит большинство студентов к атеистам (1-я строка в табл. 1) и к неверующим (2-я строка). Почти пятая часть опрошенных на первом курсе и четверть на четвертом курсе (по сумме 3-й и 4-й строк) может быть отнесена к индифферентным, т. е. безразличным и к религии, и к атеизму. Как видим, варианта, характеризующего религиозных, или хотя бы колеблющихся личностей, в таблице не приводится. Трудно представить, что такие варианты не предлагались в анкете, но в любом случае, их не могло быть более 1,9\% в 1980 г. и 0,9\% в 1983 г. (остаток после вычитания суммы всех значений в каждой графе от 100\%, табл. 1).

Таблища 1

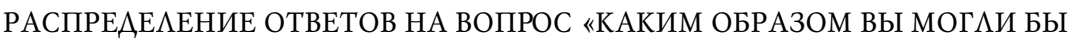

ОХАРАКТЕРИЗОВАТЬ СВОЕ ОТНОШЕНИЕ К РЕАИГИИ И АТЕИЗМУ?»,

В \%, СТУАЕНТЫ ВУЗОВ КАЗАНИ (РГАСПИ. Ф. 606. ОП. 4. А. 144. $\Lambda . ~ 84)$

Table 1

DISTRIBUTION OF ANSWERS TO THE QUESTION "HOW COULD YOU CHARACTERIZE YOUR ATTITUDE TO RELIGION AND ATHEISM?”, PER CENT, STUDENTS OF KAZAN UNIVERSITIES

\begin{tabular}{|l|c|c|}
\hline \multicolumn{1}{|c|}{ Варианты ответа } & 1980 2. & 1983 г. \\
\hline 1. Считают себя убежденными атеистами, которые могут обосновать & & \\
свою позицию & 34,4 & 38,8 \\
2. В бога не верят, но доказать несостоятельность религии не могут & 36,4 & 33,3 \\
3. Безразличны и к религии, и к атеизму & 9,1 & 11,4 \\
4. В бога не верят, но считают, что какие-то сверхъестественные силы & 16,6 & 13,3 \\
в мире существуют & 1,6 & 2,3 \\
Не ответили на вопрос & \multicolumn{2}{|c}{} \\
\hline
\end{tabular}

Некоторые вопросы анкеты были позаимствованы из изучаемого в советских вузах с 1959 г. на обязательной основе предмета «Основы научного атеизма». Социологи вынесли интересные наблюдения из ответов. На первом курсе всего $3 \%$ опрошенных дали правильный ответ на то, что представляет собой принцип свободы совести, в том виде, в каком он зафиксирован в ст. 52 Конституции СССР 2 . К четвертому курсу, когда курс ОНА большинством студентов был пройден, более или менее верный ответ дали 29,5\%, в том числе 6,1\% ответили полностью правильно.

На другой вопрос из курса научного атеизма - о согласии с утверждением о непротиворечии науки и религии $68,3 \%$ опрошенных дали полностью верный ответ («не согласен»). 
Только 4,6\% ответили, что религия положительно влияет на нравственность (ЦГАИПА РТ. Ф. 15. Оп. 12. А. 250в. А. 78).

На вопрос о роли религии в социалистическом обществе всего $0,9 \%$ согласились с тем, что «религия полезна» (табл. 2). Отметим, что при ответе на данный вопрос значительное число студентов воспользовалось возможностью уклониться от ответа (последняя строка).

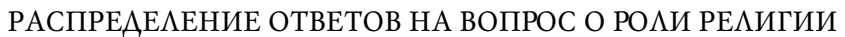

Таблица 2

В СОЦИААИСТИЧЕСКОМ ОБЩЕСТВЕ, В \%, СТУАЕНТЫ ВУЗОВ КАЗАНИ

Table 2

DISTRIBUTION OF ANSWERS TO THE QUESTION ABOUT THE ROLE OF RELIGION

IN A SOCIALIST SOCIETY, PER CENT, STUDENTS OF THE KAZAN UNIVERSITIES

\begin{tabular}{|l|c|c|}
\hline \multicolumn{1}{|r|}{ Варианты ответов } & 1980 г. & 1983 г. \\
\hline \multirow{2}{*}{ религия вредна } & 38,9 & 46,4 \\
вредна, но есть положительные моменты & 31,7 & 32,2 \\
не приносит ни вреда, ни пользы & 5,9 & 6,9 \\
религия полезна & 0,9 & 0,9 \\
не задумывались, затруднились ответить & 22,6 & 13,7 \\
\hline
\end{tabular}

Часто постулируемое в атеистической литературе неоправданное отождествление религиозных и национальных традиций (табл. 3) имело место и в студенческой среде. На первом курсе $32 \%$, а на четвертом курсе $24 \%$ выбрали вариант «религия является носительницей национальных традиций».

Таблица 3

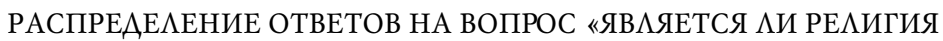

НОСИТЕАЬНИЦЕЙ НАЦИОНААЬНЫХ ТРААИЦИЙ?», В \%, СТУАЕНТЫ ВУЗОВ КАЗАНИ

Table 3

DISTRIBUTION OF ANSWERS TO THE QUESTION "IS RELIGION

THE BEARER OF NATIONAL TRADITIONS?”, PER CENT, STUDENTS OF KAZAN UNIVERSITIES

\begin{tabular}{|l|c|c|}
\hline \multicolumn{1}{|c|}{ Варианть ответов } & 1980 г. & 1983 г. \\
\hline религия является носительницей национальных традиций & 32 & 24,3 \\
носительницей национальных традиций не является & 24,1 & 26,5 \\
является иногда (не всякая религия и др. дополнения) & 3,1 & 5,7 \\
не задумывались, затруднились ответить & 40,8 & 43,5 \\
\hline
\end{tabular}

Произошедшие за годы обучения в вузе изменения в мировоззрении студентов следует признать незначительными. Так, при ответе на вопрос «Каким образом вы могли бы охарактеризовать свое отношение к религии и атеизму?» в 1980 г. давших ответ «считаю себя убежденным атеистом» было 34,4\%, а в 1983 г. стало 38,8\%. Это объясняется сквозной антирелигиозной ориентацией системы образования, которая транслировалась молодежи начиная с начальной школы. После такого «фундамента» годы обучения в вузе не играли значительной роли в атеизации личности. 
Аоступ в вузы для открыто верующей, выражаясь современным языком - «соблюдающей», молодежи был фактически закрыт, поскольку для поступления требовался пропуск в виде положительной характеристики от райкома комсомола. Однако членство в комсомоле было несовместимо с религиозной верой, это противоречило Уставу В $\Lambda \mathrm{KCM}$, которым была установлена обязанность комсомольцев решительно бороться «с религиозными предрассудками». Внутри вуза атеистическая работа не останавливалась, ее приводным ремнем и был курс «Основы научного атеизма». Протоиерей Алексий Сидоренко описывает, каким образом вузовский курс ОНА использовался лекторами для выявления верующих среди студентов для проведения с ними «индивидуальной работы». Им же дается яркая характеристика предмета: «"Научный атеизм" - это не только беззубая теория... это, прежде всего, практическая, оперативно-розыскная деятельность в полевых условиях по выявлению и перевоспитанию враждебных атеизму верующих элементов» (Сидоренко, 2010: Электронный ресурс). Нетрудно понять, что социологические опросы внутри вуза, а также внутри любого другого учреждения, предприятия могли выступать инструментом репрессивной политики. Имеется немало фактов, когда при проведении социологических опросов практически стиралась грань между научным исследованием и «индивидуальной работой с верующими».

Поэтому только полное принятие всех атрибутов и символов советской, парадной идентичности могло стать залогом получения престижной специальности и профессиональной самореализации в советском обществе. В этом заключалась суть атеистического конформизма советской молодежи. Вплоть до второй половины 1980-х гг. религиозность среди городской молодежи могла быть только латентной, неуловимой для социологических методик. В середине 1960-х гг. самые первые, а затем и все последующие социологические опросы в республиках и областях Среднего Поволжья показывали ничтожно малый процент верующих среди молодежи, высокообразованных людей и квалифицированных специалистов. При исследовании в Казани (1966 г.) в возрастной когорте 18-23-летних в абсолютном выражении нашлось всего 5 верующих на 428 неверующих, а среди 24-29-летних 25 верующих на 802 неверующих (ЦГАИПА РТ. Ф. 26. Оп. 37. А. 1089. А. 263, 264).

Первое описание достаточно уникального для современной эпохи явления латентной религиозности принадлежит исламоведу Р. Р. Мавлютову. Мавлютов обращает внимание на категорию верующих, которые, как они сами заявляют, «веруют в душе». «Верующих в душе» отличают вера в творца - Аллаха и идеалистическое представление о мире. Такие верующие не проявляют себя в обычной жизни, поскольку не посещают мечети и не участвуют в жизни мусульманских общин, молятся редко, избирательно придерживаются предписанных обрядов, не знают основ вероучения. Мавлютов подчеркивает, что пропагандисты испытывают затруднения с их выявлением. Он называет их «резервом», на который рассчитывает мусульманское духовенство (Мавлютов, 1974: 165).

В анкету 1983 г. были введены новые вопросы, связанные с анализом религиозного сознания и поведения в родительских семьях (табл. 4, см. с. 122). Выясняется, что религиозное влияние в татарских семьях было сильнее, чем в русских. Это касается большинства показателей религиозного поведения ( «соблюдаются религиозные обряды, посты», «молятся», «отмечают праздники», «имеют религиознуюлитературу» и т. А.), за исключением наличия «предметов культа» и «посещения храмов».

Сравнение результатов двух исследований (татарской молодежи Горьковской области и студентов казанских вузов) позволяет сделать вывод, что в многонацио- 
ПРОЯВАЕНИЯ РЕАИГИОЗНОГО СОЗНАНИЯ И ПОВЕАЕНИЯ

Таблица 4

В СЕМЬЕ У СТУАЕНТОВ ЧЕТВЕРТЫХ КУРСОВ, В \% (1983 Г.)

Table 4

MANIFESTATIONS OF RELIGIOUS CONSCIOUSNESS AND BEHAVIOR

IN THE FAMILY AMONG 4TH-YEAR STUDENTS OF KAZAN UNIVERSITIES, PER CENT (1983)

\begin{tabular}{|l|c|c|}
\hline \multicolumn{1}{|c|}{ Варианть ответов } & Pyсские & Tamapbl \\
\hline религиозные обряды соблюдаются в семьях & 8,7 & 15,8 \\
соблюдаются посты & 5,9 & 8,7 \\
имеются предметы культа в семьях & 24,5 & 14,9 \\
молятся & 7,2 & 11,4 \\
посещают мечеть, церковь & 6,2 & 2,7 \\
отмечают религиозные праздники & 24,8 & 30,1 \\
воспитывают детей в религиозном духе & 1,0 & 1,7 \\
верят в приметы & 24,8 & 26 \\
верят в вещие сны & 15,6 & 27 \\
верят в гадания & 7,7 & 6 \\
имеют в семье религиозную литературу & 3,2 & 6,6 \\
\hline
\end{tabular}

нальной студенческой среде религиозное влияние было минимальным. Трудно вести речь о студенческой религиозности, которая инструментарием не выявлена. Аишь у небольшой части студентов имелись приверженные религиозным традициям близкие родственники (не больше $30 \%$ у татар и $25 \%$ у русских), от которых они могли бы перенять религиозные знания, навыки и убеждения. Студенты были практически полностью лишены представлений о религиозных обрядах и вероучении. Так, всего около $1 \%$ смогли дать ответ о христианских праздниках, и 0,5\% о мусульманских. Читали ту или иную религиозную литературу $14,9 \%$ опрошенных. 48,9\% она не интересовала. Атеистическую литературу читали регулярно $1,8 \%$, редко - 22,5\%. Не читали, но собираются прочитать $13,9 \%$. Не интересует 23,9\%. Исследователи сделали вывод, что «сама религия, а нередко и атеизм находятся на периферии сознания большинства студентов» (ЦГАИПА РТ. Ф. 15. Оп. 12. А. $250 . \Lambda .80)$.

При ответах на мировоззренческие вопросы студенты демонстрировали усвоенные атеистические, материалистические взгляды. Однако при сильном падении религиозного влияния наблюдается обратный процесс - нарастание атмосферы религиозного индифферентизма. Особенно функциональными оказались варианты ответов о суевериях (о вере в приметы, в вещие сны, в судьбу, в гадания, в сглаз и т. А.), характеризующие нематериалистичность сознания (см. табл. 4).

Наличие категории индифферентных к религии и атеизму среди широких слоев взрослого населения считалось явлением нежелательным, но могло расцениваться как результат әффективной антирелигиозной пропаганды. В то же время присутствие индифферентизма в среде советской молодежи расценивалось как тревожный симптом, поскольку свидетельствовало об отсутствии твердых атеистических убеждений (Гусев, 1976: 28). 
Позднесоветский исследователь И. С. Аошакова считает, что результатом «атеистического воспитания» молодежи оказывался «в лучшем случае переход на позиции безверия, что может рассматриваться как промежуточная стадия на пути к вы-

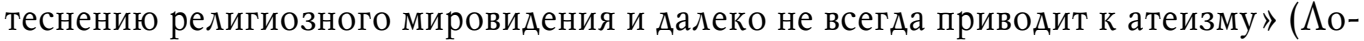
шакова, 1993: 18). Мировоззренческий индифферентизм в последние десятилетия существования советской власти сопровождался нарастанием социального пессимизма, апатии, аполитизма.

\section{ЗАКАЮЧЕНИЕ}

Социологи, изучавшие молодежь в советские времена, как и их постсоветские коллеги, находились в плену иллюзий. Им представлялось, что новые поколения, социализированные в иных условиях, чем их родители и деды, окажутся носителями иных ценностей, будут характеризоваться другой этикой и мотивацией. С чисто внешней точки зрения социологические исследования фиксировали наличие у молодежи «советских» идентичностей (советского патриотизма, интернационализма, атеизма). Однако в мировоззренческом плане молодежная среда оказалась чрезвычайно инерционной, молодежь во многом повторяла жизненные траектории предыдущего поколения. Молодежь, воспитанная на философии атеизма и материализма, не становилась автоматически носителем марксистской идеологии. Советское образование в действительности воспитывало, наряду с неприятием религиозных традиций, конформизм (приспособление) к государственной идеологии (включая государственный атеизм), с которой молодежь себя не идентифицировала. Таким образом, даже тотального запрета на воспитание детей в религиозной вере оказалось достаточно всего лишь для создания атмосферы религиозного индифферентизма в среде молодежи, однако на то, чтобы побороть религиозность, всех этих усилий не хватило.

\section{ПРИМЕЧАНИЯ}

1 В настоящее время норма добровольного участия в научных опытах вошла в российскую Конституцию (ст. 21.2).

2 «...право исповедовать любую религию или не исповедовать никакой, отправлять религиозные культы или вести атеистическую пропаганду» (Конституция СССР, 1977: 22).

\section{СПИСОК АИТЕРАТУРЫ}

Алексеев, Н. П. (1967) Методика и результаты изучения религиозности сельского населения (на материалах Орловской области) // Вопросы научного атеизма / ред. кол.: А. Ф. Окулов (отв. ред.) и др. Вып. 3. М. : Мысль. 391 с. С. 131-150.

Буйначев, К. А. (1982) Некоторые проблемы атеистического воспитания школьников // IV Уральские социологические чтения. Секция 1. Проблемы формирования научно-материалистического атеистического мировоззрения советских людей. [Тезисы докладов] / отв. ред. $\Lambda$. Н. Коган. Пермь, б/и. 51 с. С. 43-45.

Глаголев, В. С., Евдокимов, В. И. (1970). Атеистическое воспитание // Большая советская энциклопедия : в 30 т. / глав. ред. А. М. Прохоров. 3-е изд. Т. 2 [Ангола - Барзас]. М. : Сов. энциклопедия. 632 с. С. 370-371.

Галицкая, И. А (1969) К вопросу об изучении религиозности молодежи // Вопросы научного атеизма / ред. кол. : А. Ф. Окулов (отв. ред.) и др. Вып. 7. М. : Мысль. 471 с. С. 389-405.

Горшков, М. К., Шереги, Ф. Э. (2016) Российская молодежь: истоки и этапы социологического изучения // Гуманитарий Юга России. № 4. С. 11-36.

Гусев, И. С. (1976) Конкретность, научность, действенность // Вопросы научного атеизма / ред. кол.: А. Ф. Окулов (отв. ред.) и др. Вып. 19. М. : Мысль. 335 с. С. 19-31. 
Ильина, Т. А. (1968) Педагогика : учеб. пособие для студентов пед. институтов. М. : Просвещение. 572 с.

Козлов, А. С. (2013) Комсомол и самоидентификация молодежи в условиях «оттепели» 1950-1960-х гг.: на материале Европейского Севера СССР : автореф. Аис. ... канд. ист. наук. Архангельск. 213 с.

Конституция СССР (1977): Конституция (Основной Закон) Союза Советских Социалистических Республик. М. 127 с.

Иебедев, А. А. (1973). Студенческая молодежь и атеизм (некоторые итоги социологического исследования) // Вопросы научного атеизма / ред. кол.: А. Ф. Окулов (отв. ред.) и др. Вып. 15. М. : Мысль. 325 с. С. 199-213.

Мевада, Ю. А. (1965). Социальная природа религии. М. : Наука. 261 с.

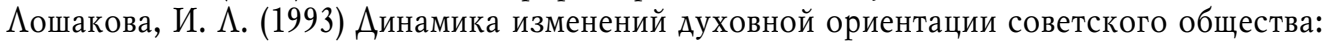
процесс секуляризации на Урале в период 1961-1985 гг. : автореф. дис. ... А-ра ист. наук. Специальность 07.00.02. Екатеринбург. 33 с.

Мавлютов, Р. Р. (1974) Ислам. 2-е изд. М. : Издательство политической литературы. 168 с.

Орлов, А. М. (1977) Проблемы атеистического воспитания населения, живущего в инонациональной среде (Исследования групп татар. населения в Горьк. и Пенз. обл.) : дис. ... канд. филос. наук. М. 198 с.

Орлов, А. (1973) О характере и структуре пережитков ислама (по материалам социологических исследований среди татарского населения Горьковской области) // Проблемы исследования структуры религиозного сознания. Тезисы докладов и выступлений / отв. ред. Е. А. Карповский. Горький : НГПИ им. М. Горького. 108 с. С. 76-93.

Рафиков, М. (1974) Тынычлану нәрсәгәилтә? // Социалистик Татарстан. 24 декабрь. 4нче бит. (на татарском).

Русакова, М. М. (2014) Обзор законодательства и литературы по этическим аспектам исследований благополучия и нарушений прав детей // Теория и практика общественного развития. № 16. С. 53-58.

Сидоренко, А. (протоиерей) (2010) «Научный атеизм»: полевые работы [Электронный ресурс] // Сибирская православная газета. №3 (март). URL: http://www.ihtus.ru/032010/st13. shtml (дата обращения: 02.03.2021).

Старостин, А. Н. (2009) Образовательные практики мусульман Урала: история и современность [Электронный ресурс] // Фаизхановские чтения. Материалы шестой ежегодной научно-практической конференции / под общ. ред. А. В. Мухетдинова. Н. Новгород : ИА «Медина» [Электронный ресурс] // Медина. Издательский дом. URL: http://www.idmedina. $\mathrm{ru} /$ books/materials/faizhanov/6/oldman.htm? (дата обращения: 02.03.2021).

Fletcher, William C., 1976: Soviet Sociology of Religion: An Appraisal// The Russian Review. Vol. 35. No. 2 (Apr.). Pp. 173-191.

Inkeles, A., Bauer, R. A. (1968) The Soviet Citizen. Daily Life in a Totalitarian Society. New York : Atheneum. 533 p.

Аата поступления: 12.05.2021 2.

\section{A SOCIOLOGICAL STUDY INTO THE RELIGIOSITY OF CHILDREN \\ AND YOUTH IN THE MIDDLE VOLGA REGION IN THE LATE SOVIET PERIOD \\ M. V. KILDEYEV \\ Republican Center for Youth, InNovative and Preventive Programs}

The purpose of the research is to consider the specifics of the sociological study into the worldview of children and youth based on the material of the Soviet sociology of religion. The scientific novelty refers to the fact that sociological data are used as a source of data on how social tendencies of secularization, ideological diktat and the reproduction of religiosity were refracted in chil- 
dren and youth. The most resonant result of the surveys within the schools is that they were conducted with disregard to any legal and ethical norms of the participation of minors in scientific research. The available material from the study of young people made it possible to carry out a comparative analysis that refers to the state of the world outlook of Soviet youth on the one hand. On the other hand, in the Tatar environment of the Gorky Region in the international student community of Kazan. The data allow us to assert a significant degree of secularization in the international Soviet student's milieu, $80 \%$ of which in the selected case consisted of white-collar and workers families children. Also, some unexpected results of the socialization of youth were recorded in the form of a wide spread of ideological conformism and religious indifference. However, contrary to the axioms, Soviet society was not homogeneous. At all times, there have been social enclaves in it, which were not subject to general social tendencies. Thus, the youth of the Tatars of the Gorky region was strongly influenced by the Muslim religion.

Keywords: soviet sociology of religion; komsomol; pioneer organization; latent religiosity; ideological conformism; religious indifference

\section{REFERENCES}

Alekseev, N. P. (1967) Metodika i rezul'taty izucheniya religioznosti sel'skogo naseleniya (na materialakh Orlovskoi oblasti). Voprosy nauchnogo ateizma / ed. board: A. F. Okulov (executive editor) and others. Issue 3. Moscow, Mysl'. 391 p. Pp. 131-150. (In Russ.).

Glagolev, V. S. and Yevdokimov, V. I. Ateisticheskoye vospitanye. Bol'shaya sovetskaya ebntsiklopediya: in 30 vols. / ed. by A. M. Prokhorov. 3d ed. Vol. 2. [Angola - Barzas]. Moscow, Soviet encyclopedia. 632 p. (In Russ.)

Buinachev, K. D. (1982) Nekotorye problemy ateisticheskogo vospitaniya shkol'nikov. In: IV Ural'skie sotsiologicheskie chteniya. Section 1. Problemy formirovaniya nauchno-materialisticheskogo ateisticheskogo mirovozzreniya sovetskikh lyudei, Reports abstracts / ed. by L. N. Koghan. Perm. 51 p. Pp. 43-45. (In Russ.).

Galitskaya, I. A. (1969) K voprosu ob izuchenii religioznosti molodezhi. In: Voprosy nauchnogo ateizma / ed. board: A. F. Okulov (executive editor) and others. Issue 7. Moscow, Mysl' publ. 471 p. Pp. 389-405. (In Russ.).

Gorshkov, M. K. and Sheregi, F. E. (2016) Rossiiskaya molodezh': istoki i etapy sotsiologicheskogo izucheniya. Gumanitarii Yuga Rossii, no 4, pp. 11-36. (In Russ.).

Gusev, I. S. (1967) Konkretnost', nauchnost', deistvennost'. In: Voprosy nauchnogo ateizma / ed. board: A. F. Okulov (executive editor) and others. Issue 19. Moscow, Mysl' publ. 335 p. Pp. 19-31. (In Russ.).

Il'ina, T. A. (1968) Pedagogika. Uchebnoe posobie dlya studentov pedagogicheskih institutov. Moscow, Prosveshchenie. 572 p. (In Russ.).

Kozlov, D. S. (2013) Komsomol $i$ samoidentifikatsiya molodezhi v usloviyakb «ottepeli» 1950-1960-kh gg.: na materiale Evropeiskogo Severa SSSR. Abstract of dis. ... Cand. of History. Arkhangelsk. 213 p. (In Russ.).

The constitution of the USSR (1977): Konstitutsiya (Osnovnoi Zakon) Soyuza Sovetskikh Sotsialisticheskikh Respublik, Moscow. (In Russ.).

Lebedev, A. A. (1973) Studencheskaya molodezh' i ateizm (nekotorye itogi sotsiologicheskogo issledovaniya). In: Voprosy nauchnogo ateizma / ed. board: A. F. Okulov (executive editor) and others. Issue 15. Moscow. 325 p. Pp. 199-213. (In Russ.).

Levada, Yu. A. (1965) Sotsial' naya priroda religii. Moscow, Nauka. 261 p. (In Russ.).

Loshakova, I. L. (1993) Dinamika izmenenii dukhovnoi orientatsii sovetskogo obshchestva: protsess sekulyarizatsii na Urale v period 1961-1985 gg. Abstract of dis. ... Dr. of History. Yekaterinburg. 33 p. (In Russ.).

Mavlyutov, R. R. (1974) Islam. 2nd edition. Moscow, Publishing house of political literature. 168 p. (In Russ.). 
Orlov, A. M. (1977) Problemy ateisticheskogo vospitaniya naseleniya, zbivushchego v inonatsional' noi srede: (Issledovaniya grupp tatarskogo naseleniya $v$ Gor'kovskoj i Penzenskojoblasti). Dis. ... Cand. of Philosophy, Moscow. 198 p. (In Russ.).

Orlov, A. (1973) O kharaktere i strukture perezhitkov islama (po materialam sotsiologicheskikh issledovanii sredi tatarskogo naseleniya Gor'kovskoi oblasti). In: Problemy issledovaniya struktury religioznogo soznaniya. Reports abstracts / ed. by E. A. Karpovskij. Gorky (Nizhny Novgorod), Nizhny Novgorod State Pedagogical Institute named after M. Gorky. 108 p. Pp. 76-93. (In Russ.).

Rafikov, M. (1974) Tynychlanu нәрсәгәилтә? Sotsialistik Tatarstan, 24 December. P. 4. (In Tatar).

Rusakova, M. M. (2014) Obzor zakonodatel'stva i literatury po eticheskim aspektam issledovanii blagopoluchiya i narushenii prav detei. Teoriya i praktika obshchestvennogo razvitiya, no 16, pp. 53-58. (In Russ.).

Sidorenko, A. (Archpriest) (2010) «Nauchnyi ateizm»: polevye raboty. Sibirskaya pravoslavnaya gazeta, no 3, March [online] Available at: http://www.ihtus.ru/032010/st13.shtml (accessed: 02.03.2021). (In Russ.).

Starostin, A. N. (2009) Obrazovatel'nye praktiki musul'man Urala: istoriya i sovremennost'. In: Faizkbanovskie chteniya. Materials of the 6th annual scientific and practical conference / ed. by D. V. Mukhetdinov. Nizhny Novgorod, Medina publishing house. Pp. 85-91 [online] Available at: http:// www.idmedina.ru/books/materials/faizhanov/6/oldman.htm? (accessed: 02.03.2021). (In Russ.).

Fletcher, William C. (1976) Soviet Sociology of Religion: An Appraisal. The Russian Review, vol. 35, no. 2 (Apr. 1976), pp. 173-191.

Inkeles, A. and Bauer, R. A. (1968) The Soviet Citizen. Daily Life in a Totalitarian Society, New York, Atheneum. 533 p.

Submission date: 12.05.2021.

Кильдеев Мансур Вилевич - кандидат социологических наук; социолог ГБУ «Республиканский центр молодежных, инновационных и профилактических программ». Адрес: 420137, Россия, Казань, ул. Адоратского, д. 36. Тел.: 8 (843) 522-55-40. Эл. адрес: makhmud_e@rambler.ru

Kildeyev Mansour Vilevich, Candidate of Sociology, Sociologist, State Budgetary Institution "Republican Center for Youth, Innovative and Preventive Programs". Postal address: 36, Adoratskogo St., Kazan, Russian Federation, 420137. Tel.: 8 (843) 522-55-40. E-mail: makhmud_e@rambler.ru 